\title{
FUTURE PREDICTION OF THE EXPANSION OF BUILT-UP AREAS IN BATAM FREE TRADE ZONE (FTZ) USING LAND CHANGE MODELER
}

\author{
Rizka Fakhira ${ }^{\mathrm{a}}$, Ari Cahyono ${ }^{\mathrm{b}, *}$ \\ ${ }^{a}$ Undergraduate Program in Cartography and Remote Sensing, Department of Geographic Information Science, Faculty of \\ Geography, Universitas Gadjah Mada, Yogyakarta, Indonesia, rizkafakhira@mail.ugm.ac.id; \\ bDepartment of Geographic Information Science, Faculty of Geography, Universitas Gadjah Mada, Yogyakarta, Indonesia, \\ aricahyono@ugm.ac.id.
}

Commission 4, WG 7

KEY WORDS: Land Change Modeler (LCM), built-up area, expansion, remote sensing, Free-Trade Zone (FTZ), Batam, Indonesia.

\begin{abstract}
The establishment of Batam City as a Free Trade Zone (FTZ) encourages the city's growth, as manifested in massive built-up area expansion. The aim of this paper was to analyze the pattern of built-up area expansion in FTZ Batam in 2035 based on the corresponding pattern from 2000 to 2015. Land Change Modeler (LCM) was the instrument used to determine and analyze land cover changes in 2000-2015, from which future changes or built-up area expansion in 2035 were predicted using the validated 2020 land cover map as reference. The validation test based on the Kappa Index of Agreement yielded 96\%. The prediction results showed that, compared with 2020, the built-up area in 2035 would have increased by $31.8 \%$ and expanded towards the outskirts of FTZ Batam. This sprawl follows the location of the primary activity centers in the FTZ, as allocated in Presidential Regulation of the Republic of Indonesia No. 87 of 2011. A new expansion is expected to continue into existing open space and extensive untouched forest areas. These research findings provide a concept that can be utilized to formulate certain policies and regional planning in the future.
\end{abstract}

\section{INTRODUCTION}

Batam is one of the largest cities in Kepulauan Riau Province that serves as a planned city and has become one of Indonesia's cities with rapid development. It is evident from built-up areas that continue to expand every year. Batam City has been designated as one of the Free-Trade Zones (FTZs) per Government Regulation of the Republic of Indonesia No. 46 of 2007 on FreeTrade Zone and Free Port in Batam. Charles W. Thurston in Harahap (2018) stated that an FTZ principally is a tax-free designated region in a country operating under rules that provide special investment incentives. The general purpose of implementing the FTZ scheme is as a means to increase economic growth. The FTZ establishment triggers the rapid growth of Batam City in various socio-economic sectors.

A prominently growing aspect is the built-up area that has increased significantly over the years. This major expansion started with an industrial boom 20 years after the establishment of Batam Island as an administrative area (Saputra \& Rachmawati, 2015). It results from the increasingly high space demand for residential and industrial purposes and other supporting facilities, which often leads to conflicts of needs for land use and incompatibility with the allocation plans (Khadiyanto, 2005). Combined with a relatively small area, this underpins good spatial planning for optimal and efficient land use.

Remote sensing technology generates spatial products in the form of imagery data. It has been used for various purposes, especially as a source of analysis in solving numerous regional problems. For example, research on urban dynamics and land cover change can utilize imagery data with multiple temporal information. Zahrotunisa and Wicaksono (2017), using Landsat images to determine land changes and predict the expansion of built-up areas in Bogor City for 2031, found a 0.3241 chance that the built-up area would expand from the northwest to the south and southeast. Despite the same observation method, the current study used a different variable, the primary activity centers in FTZ Batam.

Urbanization is characterized by built-up area development that persists every year with an increasing trend. With good planning, long-term regional development can achieve optimal and efficient land use. However, this planning requires an overview of future development patterns in order to decide and establish specific policies. Therefore, predictions of built-up area expansion in Batam City, specifically FTZ Batam, can be a reference for planning urban development and monitoring builtup area expansion.

\section{STUDY AREA}

The study area is located in FTZ Batam in Kepulauan Riau Province, whose fixed boundaries and coordinate points are defined in Article 1 Paragraph 3 of Government Regulation of the Republic of Indonesia Number 46 of 2007. In this regulation, FTZ Batam comprises Batam Island, Tonton Island, Setokok Island, Nipah Island, Rempang Island, Galang Island, and Galang Baru Island, which includes 11 (eleven) districts of Batam City. The total area of Batam City is $715 \mathrm{~km}^{2}$, and FTZ covers $661 \mathrm{~km} 2$ of its mainland.

\footnotetext{
* Corresponding Author
} 


\section{MATERIALS}

\subsection{Remote sensing imagery and built-up area map}

Multitemporal Landsat imagery is a remote sensing product with intermediate resolution and is acquired with a spatial resolution of 30 meters, except for the infrared band. Landsat images can be applied to solve numerous spatial-based problems, such as monitoring land-use changes and predicting future changes.

The Landsat images were acquired from Google Earth Engine (GEE), a platform to compute cloud-based data for various geographic data analyses (Gorelick, Hancher Matt, Dixon, Ilyushchenko, Thau, \& Moore, 2017). It can provide access to a complete catalog of remote sensing products and process these products online through massive parallelization. Landsat images used in this study were of Landsat with Tier 1 (T1) category and atmospheric correction level to Surface Reflectance (SR). The images obtained from the GEE were Landsat 7 ETM+ images in 2000 and Landsat 8 OLI images in 2015 and 2020.

The land cover map was obtained with the help of false-color composite images to present the built-up area and non-built-up area. The color composites used for the urban area analysis were /channel combinations of 753 for the Landsat 7 ETM+ image and 764 for the Landsat 8 OLI image. The supervised land cover classification used the Maximum Likelihood Classification (MLC) algorithm to obtain the maximum similarity of an unclassified vector in a class based on a predetermined class. Land cover maps were made for three years: 2000, 2015, and 2020. Land cover data from 2000 to 2015 were used as the input in future predictive modeling, while the 2020 land cover was used as a reference for the comparison process in the model accuracy testing.

\subsection{Driver variables map}

The distribution pattern of the built-up area expansion was determined using various factors potentially affecting its likelihood. Among these factors were the main road, elevation, and Central Business District (CBD). However, the factor CBD in this study was replaced with the location of the primary activity centers based on Presidential Regulation No. 87 of 2011 on Spatial Planning in Batam, Bintan, and Karimun Areas.

These factors are considered variables that control the built-up area expansion, and in the modeling, they are known as drivers. These variables were analyzed using Euclidean distance to produce a map showing distances to these variables. The distances map was then included in the determination of future land-use changes.

\section{METHODS}

\subsection{Land cover change analysis}

The early stage of this study was to analyze the land cover changes or built-up area expansion that occurred in FTZ Batam from 2000 to 2015 using the change analysis tab in the Land Change Modeler (LCM) module contained in the IDRISI TerrSet software. The analysis results of land cover changes from 2000 to 2015 were then used as the dependent variable or sub-model of change in the predictive modeling of built-up area expansion in Batam in 2035.

\subsection{Transition potential assessment}

This stage measured the possibility of land to transition in the future based on the input provided. The input consisted of a submodel of changes in the predictive modeling of the built-up area expansion (see 4.1. Land cover change analysis) and driver variable maps (i.e., distances of land to the main road, the primary activity centers in FTZ Batam, and the location of land converted into built-up areas, and Digital Elevation Model (DEM)). The algorithm used in modeling this transition variable was the Multi-Layer Perceptron (MLP) Neural Network.

\subsection{Change prediction}

Built-up area expansion was predicted following the transition potential assessment using the Markov chain matrix as a predictor of land-use changes in the following years. For validation purposes, the predictive modeling of built-up area expansion in FTZ Batam began with making predictions for the current year, namely 2020 . The results were shadow maps of the predicted built-up area expansion in FTZ Batam in 2020.

Each change prediction was modeled using a transition probability matrix, i.e., the Markov Chain matrix. This matrix was selected based on the first law of geography, the Contiguity Rule (Cabral \& Zamyatin, 2006), which states that the possibility of a cell or pixel to change is influenced by the cell or pixel closest to a particular land cover.

\subsection{Validation test}

The validation test assessed the accuracy of the derived model in predicting the built-up area expansion. For this purpose, the predicted built-up area expansion in 2020 was compared with actual land use maps in the same year. The model validity or accuracy was measured with the Kappa Index of Agreement.

\subsection{Prediction of built-up area expansion}

The built-up area expansion in FTZ Batam in 2035 was predicted after the previous modeling (see 4.4 Validation test) was declared valid or accurate. This prediction was based on the sub-model of changes in the built-up area expansion and the variables used: the distance map to the main road, the distance map to the location of the primary activity centers, the distance map to the land cover converted into a built-up area, and elevation maps.

\section{RESULTS AND DISCUSSION}

\subsection{Land cover change from 2000 to 2015}

The built-up area expansion in FTZ Batam from 2000 to 2015 is shown in Figure 1. Changes included an increase from 5,523.6 hectares in 2000 to $7,925.2$ hectares or by $43.48 \%$ in 2015 . The built-up area sprawled increasingly toward the outskirts of FTZ Batam, as identified in Sekupang, Batam Kota, Sagulung, Batu Aji, and Nongsa Districts. The conversion of non-built-up into built-up areas spread from the west to the northwest and north, i.e., from Batu Aji and Sagulung Districts to Sekupang, Batam Kota Districts, and their surroundings. This pattern and direction are thought to result from the location of the primary activity centers of FTZ Batam and the distribution of pre-existing builtup areas. 


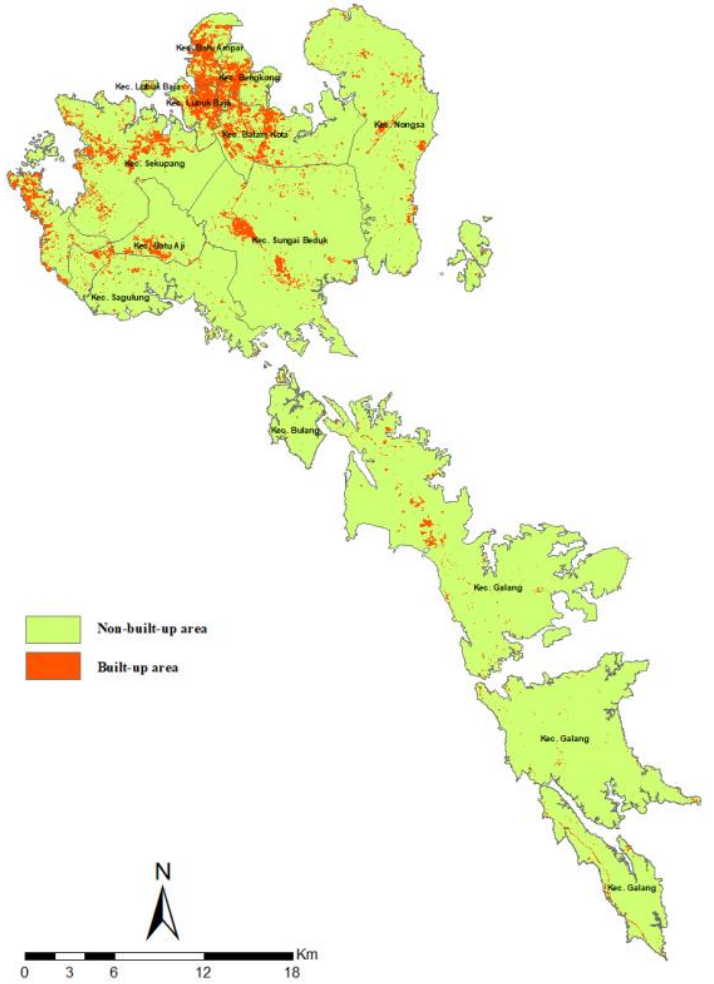

(a)

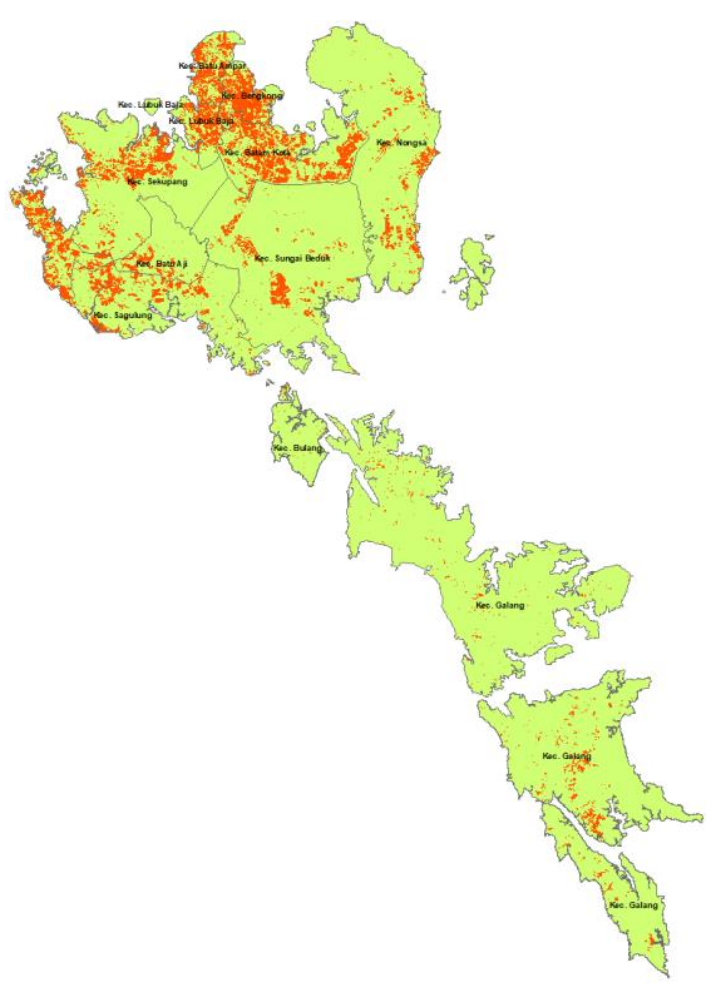

(b)

Figure 1. Land cover maps in (a) 2000 and (b) 2015. iterations. The validation test results showed that the prediction model was $81.58 \%$ accurate, which is classified as acceptable ( $\geq 80 \%$ ) according to Eastman (2016). The transition potential assessment produced a map containing the potential or the observed land cover in 2015 to transform or change, which was used as the basis for predicting land cover in FTZ Batam in 2020 The map of the transition potential is shown in Figure 2.

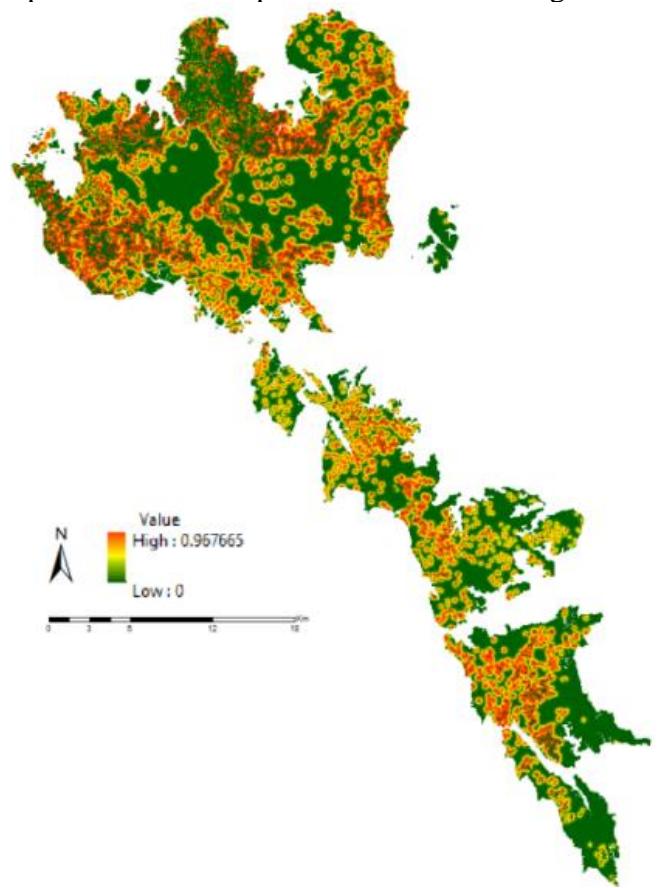

Figure 2. Transition potential map of FTZ Batam.

Based on the map, it can be seen that non-built-up areas with high potential to change into built-up land in the future are located in the west, east, and southern. The high transition potential is caused by the sub-model of change and inputted variables.

\subsection{Change detection in 2020}

The change detection was conducted in two stages: hard prediction models and soft prediction models. The hard prediction model is the result of land cover prediction modeling at a predetermined time or year, i.e., a land cover map in a certain year with land cover information or category in the legend that is the same as the inputted variables. Meanwhile, the soft prediction model is a susceptibility of a land cover to change in the selected transition set.

\subsection{Transition potential}

The parameters involved in the transition potential assessment in this study were the minimum number of cells that transitioned from 2000 to 2015 , which amounted to 59,192 cells with 10,000 


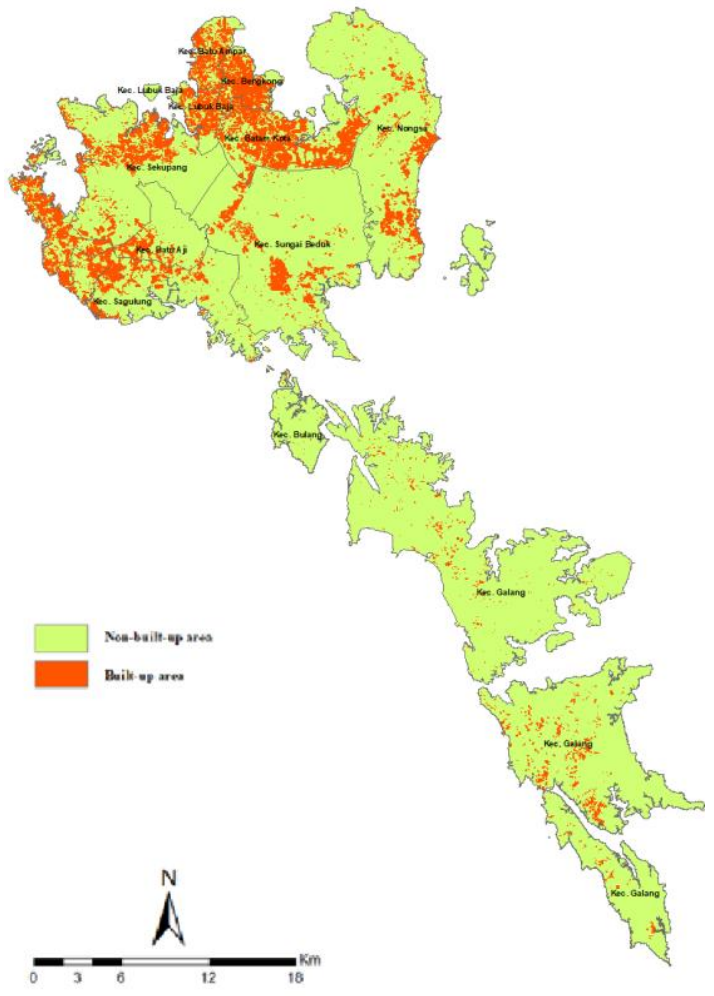

(a)

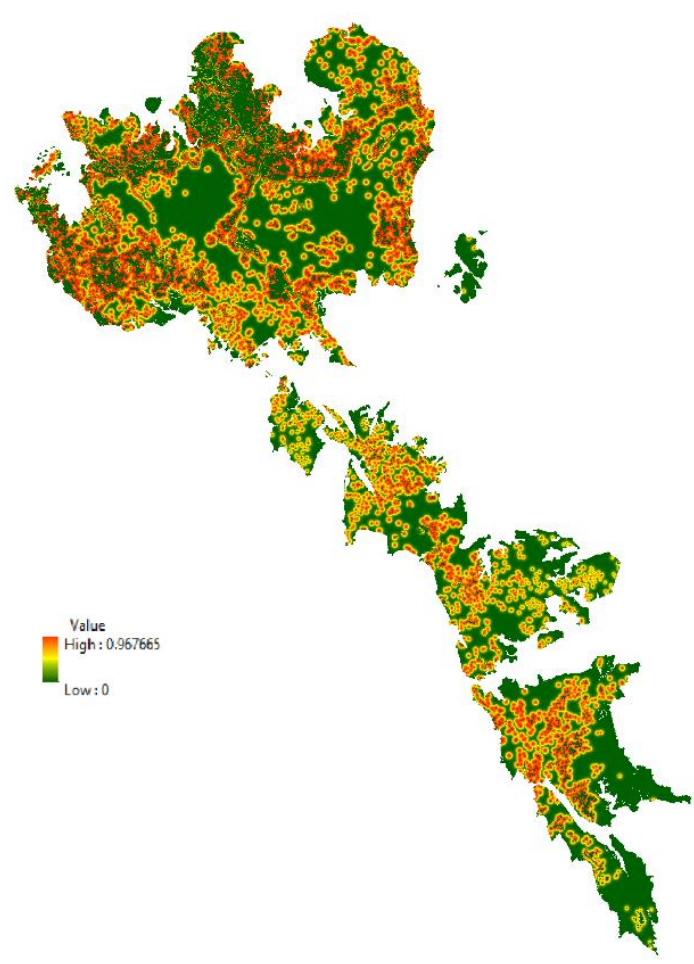

(b)

Figure 3. Maps resulting from the change detection process in 2020 : (a) soft prediction and (b) hard prediction

Figure 3 shows several differences in the hard and soft prediction models. The hard prediction yielded a map with information on land cover changes in 2020, whose classification was determined according to the inputted data: non-built-up and built-up areas. The non-built-up area is marked green, while the built-up land is in orange. The soft prediction generated a map of the susceptibility of non-built-up area conversion into built-up land that would occur in 2020, and the susceptibility is expressed in 0 to 1 . The value 0 indicates no change in the area's susceptibility, and the value 1 signifies a definite change. In other words, the lower the susceptibility value of an area, the less likely it was to change into built-up land in 2020, and vice versa, the higher the value, the greater the possibility of the said area transforming into built-up land in 2020. Areas with low susceptibility are colored green, while those with high susceptibility are in yellow to red.

The validation test compared the modeled 2020 land cover map with the one derived from Landsat 8 image classification. The test results were interpreted using the Kappa Index of Agreement, which produced index information such as $\kappa_{\mathrm{no}}, \kappa_{\text {location, }}$

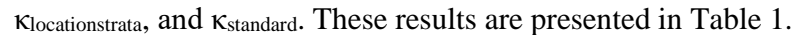

\begin{tabular}{|l|l|}
\hline Index & Value \\
\hline$\kappa_{\text {standard }}$ & 0.9327 \\
$\kappa_{\text {no }}$ & 0.9639 \\
$\kappa_{\text {location }}$ & 0.9349 \\
$\kappa_{\text {locationstrata }}$ & 0.9349 \\
\hline
\end{tabular}

Table 1. Validation test results in Kappa Index ( $\kappa)$.

$\kappa_{\text {standard }}$ measures the simulation ability to achieve perfect classification, and the predictive model in this study had a $\kappa_{\text {standard }}$ of 0.9327 . $\kappa_{\text {no }}$ denotes the overall agreement index showing the proportion of correctly classified pixels against the proportion of pixels expected to be classified correctly by the simulation to determine its accuracy. The predictive modeling in this study had a $\kappa_{\text {no }}$ of 0.9639 . Meanwhile, $\kappa_{\text {location }}$ shows the maximum possible success of the simulation to identify which location is most likely to change. In this study, the derived model had a $\kappa_{\text {location }}$ of 0.9349 . Then, the last one, $\kappa_{\text {locationstrata, describes the number of }}$ the maximum possible success of the simulation in determining the amount of pixels to land cover classes. In this study, the model had a $\kappa_{\text {locationstrata }}$ of 0.9349 . After validating the model, it was then used to predict land cover in 2035.

\subsection{Built-up area expansion in 2035}

Based on the predicted land cover map of FTZ Batam for 2035 (Figure 4), it can be seen that the non-built-up land dominantly would have occupied the existing land cover, i.e., 52,078.77 hectares or $78.5 \%$ of the total area, whereas the built-up area would amount to $14,243.85$ hectares or $21.5 \%$ (Table 2) and be concentrated in the north and west. Batam Kota District showed the most extensive distribution of the built-up land, i.e., 2,315.82 hectares or $16.3 \%$ of the total built-up area in FTZ Batam in 2035.

\begin{tabular}{|l|c|}
\hline Land Cover Type & Area (Ha) \\
\hline Built-up area & $14,243.85$ \\
Non-built-up area & $52.078,77$ \\
\hline
\end{tabular}

Table 2. Land cover area in 2035.

The built-up area expansion in 2035 was analyzed based on the expansion characteristics, namely the extent of changes and the expansion pattern and direction. The predicted map showed that the built-up area would have increased from $10,810.5$ hectares in 2020 to $14,243.9$ hectares in 2035 , or $31.76 \%$. 


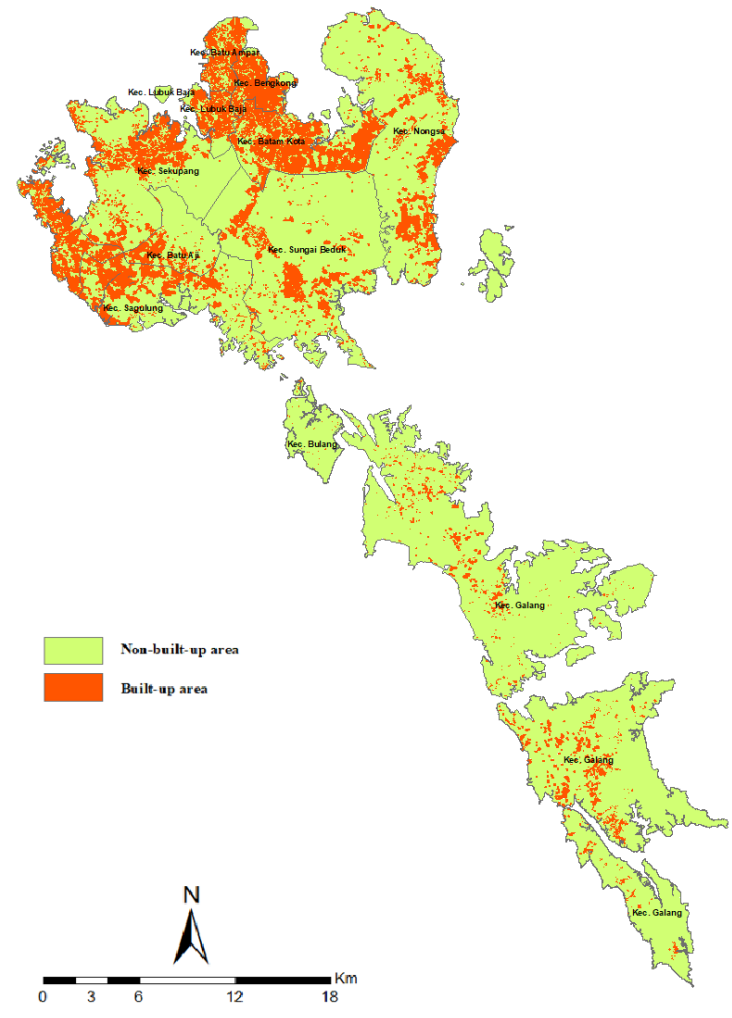

Figure 4. Land cover prediction map in 2035.

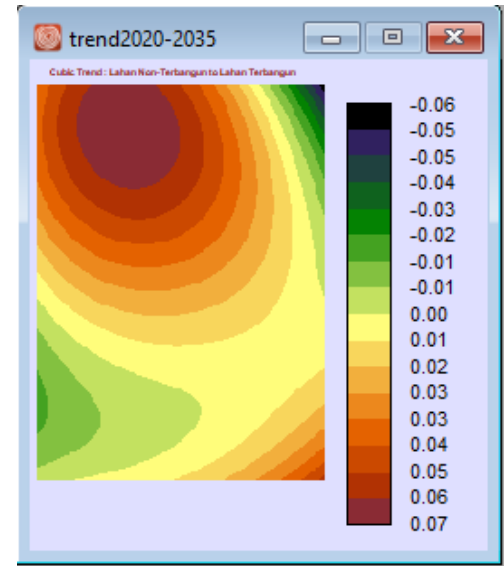

Figure 5. Cubic trend analysis in 2035.

Based on the results, it can be concluded that the built-up area expansion forms a pattern, i.e., spreading increasingly toward the outskirts of FTZ Batam, as identified in Batam Kota, Sagulung, Batu Aji, and Nongsa Districts. This land cover tends to sprawl from the southeast to the northwest and north-a direction of built-up area growth dominant in Nongsa, Batu Aji, Sagulung, Sekupang, and Batam Kota Districts. The direction also follows the point location of the primary activity centers in FTZ Batam, which is mentioned in Presidential Regulation of the Republic of Indonesia No. 87 of 2011 on Spatial Planning for the Batam, Bintan, and Karimun Regions.

\section{CONCLUSIONS}

Remote sensing technology integrated with Geographic Information Systems (GIS) can assist in observing regional problems, such as built-up area expansion. The observation can be made using the Land Change Modeler (LCM) instrument on the IDRISI TerrSet software. The study results also explain the relationship between built-up land expansion and the variables involved: distances of land to the main road, the primary activity centers, and the location of land converted into built-up areas, and Digital Elevation Model (DEM). Another alternative for similar observation is to use Google Earth Engine (GEE), a platform for computing cloud-based data for various geographic data analyses.

From 2000 to 2015, the built-up area in Free-Trade Zone (FTZ) Batam increased from 5,523.6 hectares to 7,925.2 hectares or $43.48 \%$. Meanwhile, based on the predicted model, the built-up area will increase from $10,810.5$ hectares in the reference year 2020 to $14,243.9$ hectares in 2035 , or $31.76 \%$. This expansion forms a pattern, i.e., spreading increasingly toward the outskirts of Batam City, as identified in Batam Kota, Sagulung, Batu Aji, and Nongsa Districts. This pattern is not much different from the built-up area expansion in 2000-2015. In addition, the built-up area tends to sprawl from the southeast to the northwest and north; this direction corresponds to the primary activity centers location in FTZ Batam.

\section{ACKNOWLEDGEMENTS}

The authors appreciate invaluable inputs from Dr. Bowo Susilo for this research. This research was financially supported by the Final Student Project Recognition (Rekognisi Tugas Akhir, RTA) in the fiscal year 2021, which was granted by Universitas Gadjah Mada, Yogyakarta, Indonesia, with the number 3143/UN1.P.III/DIT-LIT/PT/2021.

\section{REFERENCES}

Cabral, P., \& Zamyatin, A., 2006. Three land change models for urban dynamics analysis in Sintra-Cascais area. Proceedings of the 1stEARSel Workshop of the SIG Urban remote sensing. Humboldt-Universität $\mathrm{zu}$ Berlin, Humboldt-Universität $\mathrm{zu}$ Berlin, Berlin, Germany.

Eastman, R. J., 2016. IDRISI TerrSet Manual. Clark Labs, Worcester.

Gorelick, N., Hancher Matt, Dixon, M., Ilyushchenko, S., Thau, D., \& Moore, R., 2017. Google Earth Engine: Planetary-scale geospatial analysis for everyone. Remote Sensing of Environment, Volume 202, 18-27.

Harahap, Y. E., 2018 : Theoretical Study of Goods Traffic Control in Free Trade Zone (FTZ) in the Perspective of Legislation. Faculty of Law Universitas Jambi. Jambi, Indonesia.

Khadiyanto, P., 2005 : Tata Ruang Berbasis pada Kesesuaian Lahan. Badan Penerbit Universitas Diponegoro, Semarang, Indonesia.

Saputra, M., \& Rachmawati, R., 2015: Perkembangan Kawasan Industri dan Permukiman di Kota Batam Tahun 1997-2007. Faculty of Geography, Universitas Gadjah Mada, Yogyakarta, Indonesia.

Zahrotunisa, S., \& Wicaksono, P., 2017. Prediksi Spasial Perkembangan Lahan Terbangun Melalui Pemanfaatan Citra Landsat Multitemporal di Kota Bogor. JOIN Volume 2 No. 1, 3035 . 